\title{
INTESTINAL PARASITISM AND SOCIO-ENVIRONMENTAL FACTORS AMONG MBYÁ-GUARANI INDIANS, PORTO ALEGRE, RIO GRANDE DO SUL, BRAZIL
}

Clara Lia Costa BRANDELLI(1), Geraldo Attilio DE CARLI(2), Alexandre José MACEDO(3) \& Tiana TASCA(1)

\begin{abstract}
SUMMARY
Disturbing data reveal the prevalence of intestinal parasites and their relationship with socio-environmental factors among MbyáGuarani Indians. The prevalence was determined by spontaneous sedimentation in water, centrifugation-floatation, and Kato-Katz. A socioeconomic questionnaire was submitted to each family. The overall prevalence of intestinal parasites was $88.7 \%$, and $45.5 \%$ were polyparasitized. There was $90.5 \%$ prevalence of enteric parasites in children (1-12-year-old), and 85\% among 13-65-year-old individuals, indicating that both age groups are extensively parasitized. The parasite load was low to moderate for geohelminths and $75 \%$ of the families did not have latrine, thus the practice of defecation occurred outdoors. These findings suggest that the multiple intestinal parasitism in the Mbyá-Guarani community is high to the point of being the rule, and that it relates essentially to the traditional lifestyle and health habits. It is urgently necessary to implement the association of anti-parasitic treatment with sanitation improvement. This should be done simultaneously with health education activities for this population.
\end{abstract}

KEYWORDS: Enteroparasites; Mbyá-Guarani Indians; Polyparasitism; Indigenous health; Socio-environmental factors.

\section{INTRODUCTION}

The permanent and indiscriminate contact of indigenous populations with the national society harms their traditional and millenary cultural habits and calls forth the establishment of an environmental and cultural unbalance in the villages ${ }^{4}$. This fact results in higher susceptibility among native indigenous people to local endemic illnesses such as enteroparasitic infections ${ }^{13,18}$. The indigenous population constitutes a socioeconomically disadvantaged segment in Brazil, and it is therefore vulnerable to infectious and parasitic diseases due to lack of instruction, deficient access to drinking water, feeding, health care, personal hygiene, and basic sanitation ${ }^{2,3,13,15,16,19,20}$. The prevalence of infectious and parasitic diseases is high among Amerindian populations ${ }^{18}$. Since the Indian ethnic groups are inserted in the urban society and no proper water supply exists to enable the adequate indigenous hygiene habits, the major problem is the absence of infrastructure destined for the collection of human and domestic animal waste and the nonexistence of drinking water in the villages. A recent study shows that the Guarani population in Southern and Southeastern Brazil structure is indicative of high birth and death rates, low average age and low life expectancy at birth ${ }^{3}$. The principal causes of death were respiratory $(40.6 \%)$ and infectious and parasitic diseases (18.8\%), suggesting precarious living conditions and deficient health services ${ }^{3}$.

The interest to carry out studies on prevalence of intestinal parasites in indigenous populations rises from the fact that there are few reports in literature, and the existing ones show high rates of parasitism in these individuals ${ }^{19}$. However, these studies are still insufficient, and epidemiological surveys are imperative to contribute with new data to the knowledge of indigenous health in order to support the development of future health/public policies. Therefore, the aim of this study was to determine intestinal parasitism data and the socio-environmental factors among Mbyá-Guarani Indians from Lomba do Pinheiro, Porto Alegre, Rio Grande do Sul, Brazil.

\section{MATERIALS AND METHODS}

This study was conducted in January 2010 within the Mbyá-Guarani ethnic group, located in the district of Lomba do Pinheiro in Porto Alegre, capital of Rio Grande do Sul (RS), Brazil (30 06'47.62" S and $\left.51^{\circ} 07^{\prime} 37.85^{\prime \prime} \mathrm{W}\right)^{17}$. This ethnic group is composed of 20 families, totaling eighty persons, between one and 75 years of age.

This village is called Tekoá Anhetenguá (in English, True Village), and it covers an area of 10 hectares, where there are small crops of maize, watermelon, and peanut. The Mbyá-Guarani population produces handicrafts through sculpture as a source of income. This indigenous population is undergoing acculturation and dramatic changes in life-style, and depends on non-indigenous society for earnings. Despite this close contact with society in a large urban center, the Mbyá conserve their

(1) Laboratório de Pesquisa em Parasitologia, Departamento de Análises, Faculdade de Farmácia, Universidade Federal do Rio Grande do Sul, Porto Alegre, RS, Brazil.

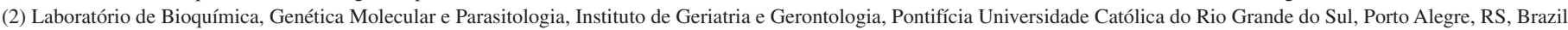

(3) Laboratório de Biofilmes e Diversidade Microbiana, Faculdade de Farmácia and Centro de Biotecnologia, Universidade Federal do Rio Grande do Sul, Porto Alegre, RS, Brazil.

Correspondence to: Dr. Alexandre José Macedo. Av. Ipiranga 2752, 90610-000 Porto Alegre, RS, Brasil. Phone: +55 (51) 3308-5325. E-mail: alexandre.macedo@ ufrgs.br 


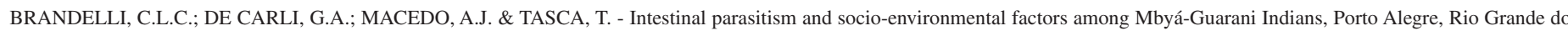
Sul, Brazil. Rev. Inst. Med. Trop. Sao Paulo, 54(3): 119-22, 2012.

culture and philosophy. The indigenous population has the possibility to use latrine infra-structure, but the great majority of them choose not to. Members of these communities live in wooden and/or brick and stone constructions with unpaved floors. Defecation occurs outdoors, whereas drinking water is supplied by DMAE (Municipal Department of Water and Sewer). There is a health care center in the village which offers medical, nursing and dental services. The non-indigenous neighborhood possesses the basic infrastructure.

The importance of this study was explained to the tribal leader of the village and, after his agreement, instructions on how to correctly collect the fecal samples were given to the population through a motivational lecture. Subsequently, the Term of Free and Clear Consent (TFCC) was read and explained to each indigenous family and then signed by each individual who accepted to participate in the study.

Three different techniques were used on a single stool sample: the spontaneous sedimentation method - HOFFMAN et al., 1934'; LUTZ, $1919^{11}$, the centrifugation-floatation method - FAUST et al., $1939^{6}$, and the quantitative method of Kato-Katz, 1972 ${ }^{4,10}$. Regarding the Kato-Katz technique, we analyzed samples which presented Ascaris lumbricoides, Trichuris trichiura and hookworms by the spontaneous sedimentation and centrifugation-floatation methods and excluded diarrheic samples. Based on the results of these tests, the following indicators were determined: prevalence of enteroparasite species according to age groups, prevalence of mono, bi and polyparasitism, most common associations between enteroparasites, and intensity of infection (parasite load) due to geohelminths (Ascaris lumbricoides, Trichuris trichiura and hookworms). Intensity of infection by geohelminths was classified as eggs per gram of feces (epg). For A. lumbricoides, low (1-4,999 epg), moderate (5,000-49,999 epg) and severe ( $\geq 50,000 \mathrm{epg})$. For T. trichiura, low (1-999 epg), moderate (1,000-9,999 epg) and severe ( $\geq 10,000$ epg). For hookworms, low (1-1,999 epg), moderate (2,000-3,999 epg) and severe $(\geq 4,000 \text { epg })^{21}$.

A questionnaire about housing and sanitation conditions was applied to the head of each indigenous family. The questions were posed in order to specify: number of cohabiting people, housing and floor material, presence of toilet, sharing the latrine or not, presence of drinking water and sewage. These questions were chosen as simple indicators of hygienic conditions, rather than specific risk factors for intestinal parasitic infections.

This study has received approval and authorization by all the following instances: (i) Research Committee, Faculdade de Farmácia, Universidade Federal do Rio Grande do Sul (UFRGS), Brazil, report no. 07/08; (ii) Research Ethics Committee, UFRGS, report no. 2007875; (ii) National Research Ethics Committee, registration no. 15092; (iii) Conselho Nacional de Pesquisa e Desenvolvimento (CNPq/Brazil); and (iv) Indian National Foundation (Fundação Nacional do Índio, (FUNAI), authorization for entering in indigenous territory no. 83/CGEP/09. At the end of the survey, the results were presented to the Chieftain and to the physician responsible for the treatment of the Mbyá-Guarani Indians.

\section{RESULTS}

The parasitological test was submitted to 62 individuals, 44 females and 18 males, aged 1-65 years-old (68\% aged between one and 12 years of age). Fecal material provided by each of the individuals was sufficient to perform the spontaneous sedimentation in water, the centrifugationfloatation, and the Kato-Katz techniques. The parasitological analysis showed that $88.7 \%$ of native people were parasitized by enteroparasites. The overall prevalence showed the highest values for Entamoeba coli (58.1\%), Ascaris lumbricoides (32.3\%), and Hymenolepis nana (30.6\%). Table 1 shows the prevalence of parasitic infections in different age groups: 1-12 and 13-65. It can be observed that $90.5 \%$ of children are infected with at least one parasite, and Entamoeba coli was the most common enteroparasite. In the other age group, the total prevalence observed was $85 \%$, the non-pathogenic protozoa $E$. coli being responsible for $75 \%$ of infections. The most significant difference between the groups was the prevalence of E. histolytica/E. dispar: among the 1-12- yearold individuals it was $14.3 \%$, and in the other age group it was $40 \%$. Most importantly, the predominant values of Strongyloides stercoralis and Enterobius vermicularis may have been underestimated, since the techniques used were not the ones most recommended for their diagnosis. The results indicated that $16 \%$ of the overall infected individuals presented infection with one parasite species (monoparasitism), 38\% presented two parasite species (biparasitism) and $45.5 \%$ were infected with more than two parasite species (polyparasitism).

\section{Table 1}

Prevalence according to enteroparasites species (\%) and age groups among Mbyá-Guarani Individuals, Porto Alegre, RS, Brazil, 2010

\begin{tabular}{lcccc}
\hline \multirow{2}{*}{ Enteroparasites } & \multicolumn{4}{c}{ Positive samples } \\
\cline { 2 - 5 } & \multicolumn{1}{c}{1 -12 } & years & $13-65$ & years \\
\cline { 2 - 5 } & $\mathrm{N}(42)$ & $\%$ & $\mathrm{~N}(20)$ & $\%$ \\
\hline Entamoeba coli & 21 & 50 & 15 & 75 \\
Ascaris lumbricoides & 16 & 38 & 4 & 20 \\
Hymenolepis nana & 14 & 33.4 & 5 & 25 \\
Endolimax nana & 12 & 28.6 & 4 & 20 \\
Giardia lamblia & 12 & 28.6 & 3 & 15 \\
Entamoeba histolytica/E. dispar & 6 & 14.3 & 8 & 40 \\
Trichuris trichiura & 5 & 11.9 & 1 & 5 \\
Hookworms & 3 & 7.1 & 1 & 5 \\
Strongyloides stercoralis & 1 & 2.4 & 1 & 5 \\
Enterobius vermicularis & 0 & - & 1 & 5 \\
\hline Total & 38 & 90.5 & 17 & 85 \\
\hline
\end{tabular}

The most frequent associations of enteroparasites species found in infections in biparasitism and polyparasitism are shown in Table 2. The severe polyparasitism cases comprise two individuals. One of them presented infection with six distinct parasites species, among which are Endolimax nana, Entamoeba coli, Giardia lamblia, Entamoeba histolytica/E. dispar, H. nana, and hookworm. The other, a child, presented infection with five enteroparasites species: A. lumbricoides, E. nana, E. coli, H. nana, E. histolytica/E.dispar.

The intensity of the infection due to A. lumbricoides was moderate in two cases, in which the quantification revealed values of 32,688 epg and 10,080 epg; and one case of low parasite load was determined with 1,488 epg. For $T$. trichiura and hookworms, low parasite loads were observed with values of 96 epg and 384 epg respectively. 
Table 2

Most common associations between enteroparasites in biparasitism and polyparasitism among Mbyá-Guarani individuals, Porto Alegre, RS, Brazil, 2010

\begin{tabular}{lc}
\hline Association of enteroparasites & Cases \\
\hline BIPARASITISM & \\
Ascaris lumbricoides and Entamoeba coli & 4 \\
Entamoeba coli and Endolimax nana & 3 \\
Endolimax nana and Giardia lamblia & 3 \\
TOTAL & $21(38 \%)^{\mathrm{a}}$ \\
\hline
\end{tabular}

\section{POLYPARASITISM}

Hymenolepis nana, Entamoeba coli and Entamoeba

histolytica/E. dispar

Hymenolepis nana, Giardia lamblia and Entamoeba

coli

Endolimax nana, Entamoeba coli and Entamoeba

histolytica/E. dispar

Giardia lamblia, Entamoeba coli and hookworms

TOTAL

${ }^{\mathrm{a}} 38 \%$ of the 55 infected individuals presented biparasitism:b $40 \%$ of the 55 infected individuals presented polyparasitism.

The questionnaire revealed the socio-environmental conditions and hygiene habits among the families studied (Table 3). Most members of this village lived in constructions made out of wood (75\%), and having a wooden $(67 \%)$, or dirt (soil-made) floor (17\%). Only $25 \%$ of houses had toilets. Consequently, the vast majority of families (75\%) defecated outdoors, on open ground. This practice is performed in the surrounding houses, contributing to soil contamination and therefore increasing the risk of contamination of individuals who walk barefoot. Furthermore, the Mbyá-Guarani ethnic group has the habit of cooking in ground fire and there is no protection of food and utensils used from contact with the contaminated ground.

\section{DISCUSSION AND CONCLUSIONS}

High infection rates due to intestinal parasites as well as the coexistence of different enteroparasitic species have been observed in Brazilian indigenous populations with harmful effects on their health, as reported among the Xavánte population (Central-West Brazil), Parakanã (Northern Brazil), Pankararu (Northeastern Brazil), Terena Indians (Central-West Brazil), Iauareté (Northern Brazil) and Kaingáng community (Southern Brazil) $)^{1,2,7,137,16,18}$. Several factors are responsible for the alarming number of parasitism in the Mbyá-Guarani village such as the practice of open defecation in the bushes surrounding the houses and the non-use of footware, especially among children ${ }^{13,15,18}$. In a personal communication of the Mbyá-Guarani Chieftain José Cirilo
Pires Morinico, "the land for the Guarani culture is more than a place to live. The land is life and it represents our origin, and therefore our habits should not be judged as something that can bring contamination, impurities and facilitate the transmission of diseases". Hence, the indigenous people do not concern themselves to use footware and to wash the hands. Furthermore, the Mbyá-Guarani people have the habit of cooking in ground fire and there is no protection of food and utensils used from contact with the contaminated ground. MOURA et al. (2010) demonstrated that the high level of soil contamination in the village located in the State of Paraná, southern Brazil, constituted a potential source of parasitic infection ${ }^{15}$.

Despite the high prevalence of intestinal parasites, the parasite load was low to moderate, for that reason this community was classified as World Health Organization (WHO) level $\mathrm{II}^{21}$. For this level of enteroparasites infections, it is recommended to have improvements in sanitation, health education and treatment for high risk groups of intestinal parasites (women of reproductive age, preschool and school children). In a previous study the antiparasitic treatment associated with sanitation improvements and educational activities were shown as controlling measures in the short term, and producing direct impact on the prevalence and parasite load ${ }^{18}$.

Our data have become even more worrisome due to the fact that $90.5 \%$ of the positive samples were from children aged one to 12 and also that the majority $(45.5 \%)$ of the population was polyparasitized. Two of them were infected with five or six different intestinal parasites. Although the indicators of undernutrition are multifactorial: parasitic infections such as those caused by A. lumbricoides, T. trichiura and hookworms can alone undermine growth due to depletion of nutrients ${ }^{5,20}$. Previous studies have shown that $H$. nana infections cause deficiency in vitamin B12 and folate, and high prevalence of undernutrition in patients ${ }^{14}$. MATOS et al. (2008) reported that $G$. lamblia infections, even asymptomatic ones, cause a negative impact on children's growth ${ }^{12}$. Although there is potable water supply, the soil contamination, by open defecation, may be responsible for these rates. E. coli and E. nana occurred at rates of $58.1 \%$ and $25.8 \%$ in the overall prevalence. Previously, these amoebae were considered to be non-pathogenic protozoa, but are now accepted as parasites of variable virulence, depending on the environmental and/ or individual conditions of the host. Furthermore, it has been shown that the species $E$. nana may be associated with diarrhea among children, if at high prevalence and intensity ${ }^{8}$.

From the standpoint of public health, it was found that the MbyáGuarani Indians were exposed to risks of infection due to the lack of sanitation and the maintenance of indigenous traditional health habits, such as the disposal of human and solid waste in the peri-domiciliary areas. The existence of some infrastructure such as local health care, school and electricity supply was also observed. In most cases, solid waste was scattered in the surroundings such as near sources of water or on the

Table 3

Socio-environmental data of the Mbyá-Guarani village from Lomba do Pinheiro, Porto Alegre, RS, Brazil ( $\mathrm{n}=62)$

\begin{tabular}{|c|c|c|c|c|c|c|c|c|c|}
\hline \multicolumn{2}{|c|}{$\begin{array}{c}\text { House } \\
\end{array}$} & \multicolumn{2}{|c|}{ Floor } & \multicolumn{2}{|c|}{ Toilet } & \multicolumn{2}{|c|}{ Sanitary facilities } & \multicolumn{2}{|c|}{ Electricity } \\
\hline Clay walls & $8 \%$ & Soil-made & $17 \%$ & Latrine & $25 \%$ & Presence & $25 \%$ & Presence & $83 \%$ \\
\hline Wood/ masonry & $75 \%$ & Wood/ masonry & $67 \%$ & No latrine & $75 \%$ & No presence & $75 \%$ & No presence & $17 \%$ \\
\hline Concrete & $17 \%$ & Concrete & $16 \%$ & & & & & & \\
\hline
\end{tabular}


BRANDELLI, C.L.C.; DE CARLI, G.A.; MACEDO, A.J. \& TASCA, T. - Intestinal parasitism and socio-environmental factors among Mbyá-Guarani Indians, Porto Alegre, Rio Grande do Sul, Brazil. Rev. Inst. Med. Trop. Sao Paulo, 54(3): 119-22, 2012.

ground. Periodic parasitological studies, including the quantification of the parasitic load are necessary for the control of intestinal parasites in the village, as well as the evaluation of policies and measures to combat infections transmissions. Therefore, health education also needs to be implemented together with sanitary policies improving the living, social, and economic conditions of this community. Thus, the presence of human and solid waste in peri-domiciliary areas associated with high prevalence of intestinal polyparasitism, the increasing urbanization and the lack of sanitation has negatively affected the quality of life of the Mbyá-Guarani Indigenous population from Lomba do Pinheiro, Rio Grande do Sul, Brazil.

\section{RESUMO}

\section{Parasitismo intestinal e fatores socioambientais de indígenas Mbyá-Guarani, Porto Alegre, Rio Grande do Sul, Brasil}

Dados preocupantes demonstram a prevalência de parasitos intestinais e sua relação com fatores socioambientais entre indígenas Mbyá-Guarani. A prevalência foi determinada pelas técnicas de sedimentação espontânea em água, centrífugo-flutuação e Kato-Katz. Para cada família, um questionário socioeconômico foi aplicado. A prevalência geral de parasitos intestinais foi de $88,7 \%$ e $45,5 \%$ estavam poliparasitados. A prevalência em crianças (1-12 anos) foi $90,5 \%$ e em indivíduos entre 13-65 anos foi $85 \%$, indicando que ambas as faixas etárias são amplamente parasitadas. A carga parasitária foi baixa a moderada para geohelmintos e 75\% das famílias não possuem banheiro, sendo a prática da defecação feita ao ar livre. Estes achados sugerem que o poliparasitismo intestinal na comunidade Mbyá-Guarani é altíssimo, a ponto de ser a regra, e que se refere essencialmente ao estilo de vida tradicional e hábitos de saúde. Há a necessidade de aplicar urgentemente a associação de tratamento antiparasitário às melhorias sanitárias. Isto deve ser feito simultaneamente com atividades de educação em saúde para esta população.

\section{ACKNOWLEDGMENTS}

The authors thank the Chieftain of the Tekoá Anhetenguá (MbyáGuarani) ethnic group, José Cirilo Pires Morinico, for making the accomplishment of this study possible and the sanitary agents of the health care center.

\section{CONFLICT OF INTEREST}

The authors declare that there are no conflicts of interest.

\section{REFERENCES}

1. Aguiar JIA, Gonçalves AQ, Sodré FC, Pereira SR, Bóia MN, Lemos ERS, et al. Intestinal protozoa and helminths among Terena Indians in the State of Mato Grosso do Sul: high prevalence of Blastocystis hominis. Rev Soc Bras Med Trop. 2007;40:631-4.

2. Bóia MN, Carvalho-Costa FA, Sodré FC, Porras-Pedroza BE, Faria EC, Magalhães GAP, et al. Tuberculosis and intestinal parasitism among indigenous people in the Brazilian Amazon region. Rev Saude Publica. 2009;43:176-8.

3. Cardoso AM, Coimbra CE Jr, Barreto CT, Werneck GL, Santos RV. Mortality among Guarani Indians in Southeastern and Southern Brazil. Cad Saude Publica. 2011;27(Suppl 2):S22-36.
4. Coimbra Jr. CEA, Santos RV. Saúde, minorias e desigualdade: algumas teias de interrelações, com ênfase nos povos indígenas no Brasil. Cien Saude Colet. 2000;5:125-32.

5. De Carli GA. Parasitologia clínica: seleção de métodos e técnicas de laboratório para o diagnóstico das parasitoses humanas. $2^{\text {nd }}$ ed. São Paulo: Atheneu; 2007. p. 29-82.

6. Faust EC, Sawitz W, Tobie J, Odom V, Peres C, Lincicome DR. Comparative efficiency of various technics for the diagnosis of protozoa and helminths in feces. J Parasit. $1939 ; 25: 241-62$

7. Fontbonne A, Freese-de-Carvalho E, Acioli MD, Sá GA, Cesse EAP. Fatores de risco para poliparasitismo intestinal em uma comunidade indígena de Pernambuco, Brasil. Cad Saude Publica. 2001;17:367-73.

8. Graczyk TK, Shiff CJ, Tamang L, Munsaka F, Beitin AM, Moss WJ. The association of Blastocystis hominis and Endolimax nana with diarrheal stools in Zambian schoolage children. Parasitol Res. 2005;98:38-43.

9. Hoffman WA, Pons JA, Janer JL. Sedimentation concentration method in schistosomiasis mansoni. Puerto Rico J Publ Hlth. 1934;9:283-98.

10. Katz N, Chaves A, Pellegrino J. A simple device for quantitative stool thick-smear technique in schistosomiasis mansoni. Rev Inst Med Trop Sao Paulo. 1972;14:397400 .

11. Lutz A. Schistosomum mansoni and schistosomiasis observed in Brazil. Mem Inst Oswaldo Cruz. 1919;11:109-40.

12. Matos SMA, Assis AMO, Prado MS, Strina A, Santos LA, Jesus SR, et al. Giardia duodenalis infection and anthropometric status in preschoolers in Salvador, Bahia State, Brazil. Cad Saude Publica. 2008;24:1527-35.

13. Miranda RA, Xavier FB, Menezes RC. Parasitismo intestinal em uma aldeia indígena Parakanã, sudeste do Estado do Pará, Brasil. Cad Saude Publica. 1998;14:507-11.

14. Mohammad MA, Hegazi MA. Intestinal permeability in Hymenolepis nana as reflected by non invasive lactulose/mannitol dual permeability test and its impaction on nutritional parameters of patients. J Egypt Soc Parasitol. 2007;37:877-91.

15. Moura FT, Falavigna DL, Mota LT, Toledo MJ. Enteroparasite contamination in peridomiciliar soils of two indigenous territories, State of Paraná, southern Brazil. Rev Panam Salud Publica. 2010;27:414-22.

16. Santos RV, Coimbra Jr. CEA, Flowers NM, Silva JP. Intestinal parasitism in the Xavante Indians, Central Brazil. Rev Inst Med Trop São Paulo. 1995;37:145-8.

17. Souza JOC, Moraes CEN, Pires DM, Morinico JCP, Arnt MA. Tava Miri São Miguel Arcanjo, Sagrada Aldeia de Pedra: os Mbyá-Guarani nas Missões. Porto Alegre: $12^{\circ} \mathrm{SR}$ - IPHAN; 2007

18. Toledo MJO, Paludetto AW, Moura FT, Nascimento ES, Chaves M, Araújo SM, et al. Evaluation of enteroparasite control activities in a Kaingáng community of Southern Brazil. Rev Saude Publica. 2009;43:981-90.

19. Vieira GO. Enteroparasitoses em populações indígenas no Brasil: uma revisão sistemática da produção científica. [dissertação]. Rio de Janeiro: Escola Nacional de Saúde Pública, Fundação Oswaldo Cruz; 2003.

20. Zonta ML, Oyhenart EE, Navone GT. Nutritional status, body composition, and intestina parasitism among the Mbyá-Guaraní communities of Misiones, Argentina. Am J Hum Biol. 2010;22:193-200

21. World Health Organization. Prevention and control of Schistosomiasis and soil-transmitted helminthiasis. Geneva: WHO; 2002. (WHO Technical Report Series 912).

Received: 10 October 2011

Accepted: 24 February 2012 